8. Look Up Full Text $\quad$ Full Text from Publisher $\quad$ EN Find PDF $G$ Export... $\quad$ Add to Marked List

\section{Assessment of Free radical scavenging and digestive enzyme inhibitory activities of extract, fractions and isolated compounds from Tetracera macrophylla leaves}

By: Roheem, FO (Roheem, F. O.) ${ }^{[1]}$; Ahmed, QU (Ahmed, Q. U.) ${ }^{[1]}$; So' ad, SZM (So'ad, S. Z. Mat) ${ }^{[1]}$; Shah, SAA (Shah, S. A. A.) $)^{[2,3]}$; Latip, J (Latip, J. $]^{[4]}$; Alhassan, AM (Alhassan, A. M.) ${ }^{[1]}$; Mohammad, SNAS (Mohammad, S. N. A. Syed) ${ }^{[1]}$

View Web of Science ResearcherID and ORCID

\section{JOURNAL OF HERBAL MEDICINE}

Volume: 22

Article Number: 100351

DOI: $10.1016 /$ j.hermed.2020.100351

Published: AUG 2020

Document Type: Article

View Journal Impact

\section{Abstract}

Tetracera macrophylla is a valuable medicinal plant used traditionally for the treatment of various ailments. The crude ethanol extract was analyzed for its total phenolic and flavonoid contents. 2, 2-diphenyl-1-picrylhydrazyl (DPPH) and 2,2'-azinobis-3-ethylbenzothiazine-6-sulfonic acid (ABTS) were used to examine the free radical scavenging capacity while enzyme inhibitory activity was assessed using alpha-amylase and alpha-glucosidase inhibitory methods. The crude extract was found to be rich in both phenolic and flavonoid contents (417.90 and 5.86 mu g GAE and QUE/mg dry weight, respectively) thus exhibited good radical scavenging activity on DPPH and ABTS radicals (IC50 values of 16.2 and $14.65 \mathrm{mu} \mathrm{g} / \mathrm{mL}$, respectively). It also showed a promising concentration dependent enzymes inhibitory activity against alpha-amylase and alpha-glucosidase with IC50 of 72.17 and $76.16 \mathrm{mu}$ g/mL, respectively. Fractionation of active ethanol extract of T. macrophylla leaves through liquid-liquid partitioning yielded fractions $\mathrm{Fa}$, $\mathrm{Fb}$, Fc, and Fd. Among all the fractions, Fb (ethyl acetate fraction) showed the highest phenolic and flavonoid contents (206.34 mu g/GAE and $4.01 \mathrm{mu}$ g/QUE respectively) and was also found to exhibit highest antioxidant and alphaglucosidase inhibitory activities. The most active fraction, $\mathrm{Fb}$ upon purification yielded five compounds which were characterized and identified through different spectroscopic techniques. FTQ-4 among the compounds exhibited the strongest free radical and enzyme inhibitory activities followed by FTQ-3. All the compounds were isolated from this plant for the first time and found active against free radicals and/or digestive enzymes. These results further suggest the medicinal potential of T. macrophylla leaves as a therapeutic agent against hyperglycemia and free radical associated problems.

\section{Keywords}

Author Keywords: Tetracera macrophylla; DPPH; ABTS; alpha-glucosidase; alpha-amylase; Active principles KeyWords Plus: ALPHA-AMYLASE; ANTIOXIDANT ACTIVITY; IN-VITRO; LEAF EXTRACT; SCANDENS L.; GLUCOSIDASE; PLANTS; FLAVONOIDS

\section{Author Information}

Reprint Address:

International Islamic University Malaysia Int Islamic Univ Malaysia, Dept Pharmaceut Chem, Kuantan 25200, Pahang Dm, Malaysia.

Corresponding Address: Ahmed, QU; So'ad, SZM (corresponding author)

+ Int Islamic Univ Malaysia, Dept Pharmaceut Chem, Kuantan 25200, Pahang Dm, Malaysia.

Addresses:

+ [1] Int Islamic Univ Malaysia, Dept Pharmaceut Chem, Kuantan 25200, Pahang Dm, Malaysia

[2 ] Univ Teknol MARA, Atta Ur Rahman Inst Nat Prod Discovery AuRIns, Bandar Puncak Alam, Selangor Darul, Malaysia

[3] Univ Teknol MARA, Fac Pharm, Puncak Alam Campus, Bandar Puncak Alam 42300, Selangor Darul, Malaysia

+ [4] Univ Kebangsaan Malaysia, Fac Sci \& Technol, Sch Chem Sci \& Food Technol, Bandar Baru Bangi 43600, Selangor, Malaysia

E-mail Addresses: quahmed@iium.edu.my; dszaiton@iium.edu.my

Funding

\section{Citation Network}

In Web of Science Core Collection

\section{2}

Times Cited

Create Citation Alert

All Times Cited Counts

2 in All Databases

See more counts

\section{7}

Cited References

View Related Records

(i) New! You may also like... ${ }^{\text {BETA }}$

Antidiabetic effects of Brucea javanica seeds in type 2 diabetic rats. BMC COMPLEMENTARY AND ALTERNATIVE MEDICINE (2017)

Isolation of quercetin and mandelic acid from Aesculus indica fruit and their biological activities.

BMC BIOCHEMISTRY (2018)

A fraction of Acorus calamus L. extract devoid of beta-asarone enhances adipocyte differentiation in 3T3-L1 cells. PHYTOTHERAPY RESEARCH (2007)

Antiulcer activity of the ethanolic extract and ethyl acetate fraction of the leaves of Markhamia tomentosa in rats. JOURNAL OF ETHNOPHARMACOLOGY (2014)

PURINE NUCLEOSIDE PHOSPHORYLASE INHIBITORS - SYNTHESIS AND ENZYMEINHIBITORY ACTIVITY OF 9-SUBSTITUTED9-DEAZA HYPOXANTHINES. ABSTRACTS OF PAPERS OF THE AMERICAN CHEMICAL SOCIETY (1994)

View all suggestions

\section{Most recently cited by:}

Saleh, Mohammed S. M.; Jalil, Juriyati; Mustafa, Nor Hidayah; et al. UPLC-MS-Based Metabolomics Profiling for alpha-Glucosidase Inhibiting Property of Parkia speciosa Pods. LIFE-BASEL (2021)

Mohamed, Tiss; Souiy, Zoubeida; Achour Lotfi; et al.

Anti-obesity, anti-hyperglycaemic, antiantipyretic and analgesic activities ofGlobularia alypumextracts. ARCHIVES OF PHYSIOLOGY AND BIOCHEMISTRY (2020)

View All 


\begin{tabular}{|c|c|}
\hline Funding Agency & Grant Number \\
\hline Ministry of Education, Malaysia & $\begin{array}{l}\text { FRGS } 13-089-0330 \\
\text { FRGS } 16-042-0541\end{array}$ \\
\hline Research Management Center, IIUM, Malaysia & RIGS 16-294-0458 \\
\hline
\end{tabular}

View funding text

Publisher

ELSEVIER GMBH, HACKERBRUCKE 6, 80335 MUNICH, GERMANY

Journal Information

Impact Factor: Journal Citation Reports

Categories / Classification

Research Areas: Integrative \& Complementary Medicine

Web of Science Categories: Integrative \& Complementary Medicine

See more data fields

\section{Use in Web of Science}

Web of Science Usage Count

1

Last 180 Days $\quad$ Since 2013

Learn more

This record is from:

Web of Science Core Collection

- Science Citation Index Expanded

\section{Suggest a correction}

If you would like to improve the quality of the data in this record, please suggest a correction.

\section{Cited References: 57}

Showing $\mathbf{3 0}$ of $\mathbf{5 7} \quad$ View All in Cited References page

1. Total phenolic contents and free radical scavenging activity of certain Egyptian Ficus species leaf samples

By: Abdel-Hameed, El-Sayed Saleh

FOOD CHEMISTRY Volume: 114 Issue: 4 Pages: 1271-1277 Published: JUN 152009

2. Phytochemical analysis and antioxidant activity of methanol extract and betulinic acid isolated from the roots of

Times Cited: 13

Tetracera potatoria.

By: Adesanwo, J. K.; Makinde, O. O.; Obafemi, C. A.

Journal of Pharmacy Research Volume: 6 Issue: 9 Pages: 903-907 Published: 2013

3. Antioxidant activity and phenolic profile of various morphological parts of underutilised Baccaurea angulata fruit

By: Ahmed, Idris Adewale; Mikail, Maryam Abimbola; Bin Ibrahim, Muhammad; et al.

Times Cited: 33

FOOD CHEMISTRY Volume: 172 Pages: 778-787 Published: APR 12015

4. A new sulphated flavone and other phytoconstituents from the leaves of Tetracera indica Merr. and their alpha-

Times Cited: 8

glucosidase inhibitory activity

By: Alhassan, Alhassan Muhammad; Ahmed, Qamar Uddin; Latip, Jalifah; et al.

NATURAL PRODUCT RESEARCH Volume: 33 Issue: 1 Pages: 1-8 Published: JAN 22019

5. alpha-amylase inhibitory activity of some Malaysian plants used to treat diabetes; with particular reference to Phyllanthus amarus

By: Ali, Hasenah; Houghton, P. J.; Soumyanath, Amala

JOURNAL OF ETHNOPHARMACOLOGY Volume: 107 Issue: 3 Pages: 449-455 Published: OCT 112006

6. Diagnosis and classification of diabetes mellitus.

Times Cited: 1,147

Corporate Author(s): American Diabetes Association

Diabetes care Volume: 27 Suppl 1 Pages: S5-S10 Published:2004-Jan

7. Radical scavenging activity of various extracts and fractions of sweet orange-peel (Citrus sinensis)

Times Cited: 261

By: Anagnostopoulou, MA; Kefalas, P; Papageorgiou, VP; et al.

FOOD CHEMISTRY Volume: 94 Issue: 1 Pages: 19-25 Published: JAN 2006

8. Antihyperglycemic activity of polyphenolic components of black/bitter cumin Centratherum anthelminticum (L.) Kuntze Times Cited: 40 seeds

By: Ani, V.; Naidu, K. Akhilender

EUROPEAN FOOD RESEARCH AND TECHNOLOGY Volume: 226 Issue: 4 Pages: 897-903 Published: FEB 2008

9. alpha-glucosidase inhibitory activity of triterpenoids from Cichorium intybus

Times Cited: 50

By: Atta-Ur-Rahman; Zareen, Seema; Choudhary, M. Iqbal; et al.

JOURNAL OF NATURAL PRODUCTS Volume: 71 Issue: 5 Pages: 910-913 Published: MAY 2008

10. Antidiabetic Medicinal Plants as a Source of Alpha Glucosidase Inhibitors

Times Cited: 153

By: Benalla, Wafaa; Bellahcen, Said; Bnouham, Mohamed

CURRENT DIABETES REVIEWS Volume: 6 Issue: 4 Pages: 247-254 Published: 2010 
11. Title: [not available]

By: BHAT M

EVID-BASED COMPLALT Pages: 1 Published: 2011

12. Isolation and characterisation of methanol-soluble fraction of Alternanthera philoxeroides (Mart.) - evaluation of their

antioxidant, alpha-glucosidase inhibitory and antimicrobial activity in in vitro systems

By: Bhattacherjee, Abhishek; Ghosh, Tanushree; Sil, Rajarshi; et al.

NATURAL PRODUCT RESEARCH Volume: 28 Issue: 23 Pages: 2199-2202 Published: 2014

13. Technical evaluation of antioxidant activity

Times Cited: 32

By: Boligon, A.A.

Med.Chem. Volume: 4 Pages: 517-522 Published:2014

14. Glycosidase inhibitors: a patent review (2008-2013)

Times Cited: 41

By: Bras, Natercia F.; Cerqueira, Nuno M. F. S. A.; Ramos, Maria J.; et al.

EXPERT OPINION ON THERAPEUTIC PATENTS Volume: 24 Issue: 8 Pages: 857-874 Published: AUG 2014

15. Screening of antioxidant activity and antioxidant compounds of some edible plants of Thailand

Times Cited: 242

By: Chanwitheesuk, A; Teerawutgulrag, A; Rakariyatham, N

FOOD CHEMISTRY Volume: 92 Issue: 3 Pages: 491-497 Published: SEP 2005

16. Dipeptidyl peptidase-4 inhibitors in the treatment of type 2 diabetes: a comparative review

Times Cited: 320

DIABETES OBESITY \& METABOLISM Volume: 13 Issue: 1 Pages: 7-18 Published: JAN 2011

17. Bioautography and its scope in the field of natural product chemistry.

Times Cited: 55

By: Dewanjee, Saikat; Gangopadhyay, Moumita; Bhattacharya, Niloy; et al.

Journal of pharmaceutical analysis Volume: 5 Issue: 2 Pages: 75-84 Article Number: 2095-1779(2015)5:2<75:BAISIT>2.0.TX;2-U

Published: 2015 -Apr (Epub 2014 Jun 26)

18. Isolation and structure elucidation of antioxidant compounds from leaves of Laurus nobilis and Emex spinosus

By: Emam, Ahmed M.; Mohamed, Mamdouh A.; Diab, Yasser M.; et al.

Times Cited: 20

DRUG DISCOVERIESAND THERAPEUTICS Volume: 4 Issue: 3 Pages: 202-207 Published: JUN 2010

19. Secondary metabolites from Tetracera potatoria stem bark with anti-mycobacterial activity

Times Cited: 9

By: Fomogne-Fodjo, M. C. Y.; Ndinteh, D. T.; Olivier, D. K.; et al.

JOURNAL OF ETHNOPHARMACOLOGY Volume: 195 Pages: 238-245 Published: JAN 42017

20. 5,7-DIHYDROXY-8-METHOXYFLAVONE FROM TETRACERA-INDICA

Times Cited: 17

By: HARRISON, LJ; SIA, GL; SIM, KY

PLANTA MEDICA Volume: 60 Issue: 5 Pages: 493-494 Published: OCT 1994

21. Flavonoids from Tetracera indica Merr. induce adipogenesis and exert glucose uptake activities in 3T3-L1 adipocyte cells Times Cited: 12 By: Hasan, Md. Mahmudul; Ahmed, Qamar Uddin; Soad, Siti Zaiton Mat; et al.

BMC COMPLEMENTARY AND ALTERNATIVE MEDICINE Volume: 17 Article Number: 431 Published: AUG 302017

22. A study of antioxidant activity, enzymatic inhibition and in vitro toxicity of selected traditional sudanese plants with anti- Times Cited: 13 diabetic potential

By: Hilmi, Yasmin; Abushama, Muna F.; Abdalgadir, Haidar; et al.

BMC COMPLEMENTARY AND ALTERNATIVE MEDICINE Volume: 14 Article Number: 149 Published: MAY7 2014

23. Comparison of antioxidant potential and rat intestinal \&alpha;-glucosidases inhibitory activities of quercetin, rutin, and Times Cited: 65 isoquercetin

By: Jo, SH; Ka, EH; Lee, HS; et al.

Int J Appl Res Nat Prod Volume: 2 Pages: 52-60 Published: 2009

[Show additional data]

24. Cultivar Evaluation and Effect of Fermentation on Antioxidant Capacity and in Vitro Inhibition of alpha-Amylase and alpha-Glucosidase by Highbush Blueberry (Vaccinium corombosum)

By: Johnson, Michelle H.; Lucius, Anita; Meyer, Tessa; et al.

JOURNAL OF AGRICULTURAL AND FOOD CHEMISTRY Volume: 59 Issue: 16 Pages: 8923-8930 Published: AUG 242011

25. Inhibitory effect of Azadirachta indica A. juss leaf extract on the activities of alpha-amylase and alpha-glucosidase.

By: Kazeem, M I; Dansu, T V; Adeola, S A

Pakistan journal of biological sciences: PJBS Volume: 16 Issue: 21 Pages: 1358-62 Published: 2013 -Nov-01

26. Comparative Evaluation of Quercetin, Isoquercetin and Rutin as Inhibitors of alpha-Glucosidase

Times Cited: 285

By: Li, Yan Qin; Zhou, Feng Chao; Gao, Fei; et al.

JOURNAL OF AGRICULTURAL AND FOOD CHEMISTRY Volume: 57 Issue: 24 Pages: 11463-11468 Published: DEC 232009 
27. Chemical constituents, larvicidal effects and radical scavenging activity of Tetracera breyniana Schltdl. (Dilleniaceae).

By: Lima, C. C. de; Lemos, R. P. L.; Conserva, L. M.

Journal of Applied Pharmaceutical Science Volume: 3 Issue: 9 Pages: 14-18 Published: 2013

28. In vitro alpha-glucosidase inhibitory activity of isolated fractions from water extract of Qingzhuan dark tea

By: Liu, Shuyuan; Yu, Zhi; Zhu, Hongkai; et al.

Times Cited: 37

BMC COMPLEMENTARY AND ALTERNATIVE MEDICINE Volume: 16 Article Number: 378 Published: SEP 292016

29. Flavonoids for controlling starch digestion: Structural requirements for inhibiting human alpha-amylase By: Lo Piparo, Elena; Scheib, Holger; Frei, Nathalie; et al.

Times Cited: 198

JOURNAL OF MEDICINAL CHEMISTRY Volume: 51 Issue: 12 Pages: 3555-3561 Published: JUN 262008

30. DNA polymerase beta inhibitors from Tetracera boiviniana

Times Cited: 42

By: Ma, J; Starck, SR; Hecht, SM

JOURNAL OF NATURAL PRODUCTS Volume: 62 Issue: 12 Pages: 1660-1663 Published: DEC 1999

Showing $\mathbf{3 0}$ of $\mathbf{5 7} \quad$ View All in Cited References page 